\title{
Massilia flava sp. nov., isolated from soil
}

\author{
Correspondence \\ Jianli Zhang \\ zhangjianli@bit.edu.cn
}

\author{
Jiewei Wang, ${ }^{1}$ Jianli Zhang, ${ }^{1}$ Huancheng Pang, ${ }^{2}$ Yabo Zhang, ${ }^{1}$ Yuyi $\mathrm{Li}^{2}$ \\ and Jinping Fan $^{1}$ \\ ${ }^{1}$ School of Life Science, Beijing Institute of Technology, Beijing 100081, PR China \\ ${ }^{2}$ Institute of Agri-resources and Regional Planning, CAAS, Beijing 100081, PR China
}

The genus Massilia was proposed by La Scola et al. (1998) with the description of Massilia timonae, isolated from the blood of an immunocompromised patient with cerebellar lesions. Subsequently, the genus Naxibacter was described by Xu et al. (2005) on the basis of differential phenotypic characteristics from closely related genera. However, differences between Massilia and Naxibacter were not genus-specific. Furthermore, the two genera shared identical chemotaxonomic properties. Consequently, Kämpfer et al. (2011) proposed the transfer of all Naxibacter species to the genus Massilia. At the time of writing, the genus Massilia thus comprises 16 recognized species, isolated from air, soil and water (La Scola et al., 1998; Xu et al., 2005; Gallego et al., 2006; Kämpfer et al., 2008, 2011; Zhang et al., 2006; Zul et al., 2008; Weon et al., 2008, 2009, 2010). Members of the genus Massilia are Gram-negative and have relatively high DNA $\mathrm{G}+\mathrm{C}$ contents. Chemotaxonomically, members of this genus contain summed feature $3\left(\mathrm{C}_{16: 1} \omega 7 c\right.$ and/or iso$\left.\mathrm{C}_{15: 0} 2-\mathrm{OH}\right)$ and $\mathrm{C}_{16: 0}$ as major fatty acids and Q-8 as the predominant isoprenoid quinone.

In this study, we describe a Massilia-like soil isolate, designated strain $\mathrm{Y}^{\mathrm{T}}$. The organism was considered to be

The GenBank/EMBL/DDBJ accession number for the 16S rRNA gene sequence of strain $\mathrm{Yg}^{\top}$ is $\mathrm{HM} 777013$.

A supplementary figure is available with the online version of this paper.
Massilia-like on the basis of preliminary 16S rRNA gene sequence analysis. Accordingly, the aim of present work was to elucidate the taxonomic position of strain $\mathrm{Y}^{\mathrm{T}}$, based on a combination of phenotypic, genetic and chemotaxonomic analyses.

Strain $\mathrm{Y}^{\mathrm{T}}$ was originally isolated from a soil sample from Ningxia Province in China. For isolation, the soil sample $(1 \mathrm{~g})$ was suspended in distilled water $(100 \mathrm{ml})$ and spread on plates of ISP2 medium after serial dilution. Plates were incubated at $28{ }^{\circ} \mathrm{C}$ for 3 days. Single colonies were purified by transferring them onto new plates and were incubated again on the same medium. ISP2 medium contained the following $\left(\mathrm{l}^{-1}\right)$ : $4 \mathrm{~g}$ yeast extract, $10 \mathrm{~g}$ malt extract, $4 \mathrm{~g}$ glucose and $20 \mathrm{~g}$ agar. The medium was adjusted to $\mathrm{pH}$ 7.5 with $1 \mathrm{mM} \mathrm{NaOH}$. Purified colonies were tentatively identified from partial sequences of the 16S rRNA gene. Strain $\mathrm{Y} 9^{\mathrm{T}}$ was maintained on ISP2 agar at $4{ }^{\circ} \mathrm{C}$ and as glycerol suspensions $(20 \%, \mathrm{v} / \mathrm{v})$ at $-20{ }^{\circ} \mathrm{C}$.

Cellular morphological characteristics of strain $\mathrm{Y}^{\mathrm{T}}$ were examined by light microscopy (BH-2; Olympus) after $24 \mathrm{~h}$ growth on ISP 2 medium at $28{ }^{\circ} \mathrm{C}$. Colonial properties were examined after 3 days of growth at $28^{\circ} \mathrm{C}$ on ISP2 medium. Phenotypic characteristics such as Gram staining, catalase and oxidase activities and hydrolysis of casein, Tween 80 and starch were performed by using the methods of Smibert \& Krieg (1994). Growth at 4, 10, 28, 37, 40, 45 and 
$55{ }^{\circ} \mathrm{C}$ was measured on ISP2 medium. The $\mathrm{pH}$ range ( $\mathrm{pH} 4-10$ at intervals of $0.5 \mathrm{pH}$ units) for growth and the requirement for $\mathrm{NaCl}[0,1,2,3,5$ and $7 \%(\mathrm{w} / \mathrm{v})]$ were determined as described by $\mathrm{Xu}$ et al. (2005). The commercially available API test kits (bioMérieux) were used to determine the biochemical properties, utilization of carbohydrates and enzyme activities of the novel strain. Tests were generally performed according to the manufacturer's instructions. The API ZYM tests were read after $4 \mathrm{~h}$ incubation at $37{ }^{\circ} \mathrm{C}$ and the other API tests were read after $72 \mathrm{~h}$ at $28{ }^{\circ} \mathrm{C}$.

Strain $\mathrm{Y}^{\mathrm{T}}$ was a Gram-stain-negative, non-spore-forming bacterium. Cells were rod-shaped $(0.6-0.8 \times 1.5-2.5 \mu \mathrm{m})$ with round ends. Colonies were circular to irregular, convex, yellow and $1-3 \mathrm{~mm}$ in diameter after 3 days of cultivation at $28{ }^{\circ} \mathrm{C}$ on ISP2 medium. Strain $\mathrm{Yg}^{\mathrm{T}}$ grew optimally at $28-30{ }^{\circ} \mathrm{C}$ (range $10-45^{\circ} \mathrm{C}$ ) and did not grow in the presence of more than $1 \%(\mathrm{w} / \mathrm{v}) \mathrm{NaCl}$. Growth was observed at pH 6.5-8.5 (optimally at $\mathrm{pH}$ 7.0-7.5). Catalase activity and oxidase activity were present. The phenotypic properties of strain $\mathrm{Y}^{\mathrm{T}}$ are summarized and compared with those of related species of the genus Massilia in Table 1 and are given in the species description.

Biomass for chemotaxonomic studies was obtained after incubation at $28{ }^{\circ} \mathrm{C}$ for 3 days in shake flasks of tryptone soy broth (TSB; Oxoid). Ubiquinones were extracted and purified according to the methods of Collins et al. (1987); purified ubiquinones were identified by reversed-phase HPLC (Wu et al., 1989). Polar lipids were extracted according to the method of Minnikin et al. (1979) and polar lipid profiles were analysed according to Collins \& Jones (1980). Genomic DNA of strain $\mathrm{Y}^{\mathrm{T}}$ for G+C content determination was prepared according to the method of Marmur \& Doty (1962). Whole-cell fatty acids were analysed by using the standard Microbial Identification System (MIDI) (Sasser, 1990; Kämpfer \& Kroppenstedt,

Table 1. Differential characteristics between strain $Y 9^{\top}$ and the type strains of closely related species of the genus Massilia

Strains: 1 , Y9 ${ }^{\mathrm{T}} ; 2$, M. aerilata KACC $12505^{\mathrm{T}} ; 3$, M. albidiflava KCTC $12343^{\mathrm{T}} ; 4$, M. aurea DSM $18055^{\mathrm{T}} ; 5$, M. brevitalea DSM $18925^{\mathrm{T}} ; 6$, M. dura $^{2}$ KCTC $12342^{\mathrm{T}}$; 7, M. lutea KCTC $12345^{\mathrm{T}}$; 8, M. niabensis DSM $21312^{\mathrm{T}}$; 9, M. niastensis DSM $21313^{\mathrm{T}}$; 10, M. plicata KCTC $12344^{\mathrm{T}}$; 11 , M. timonae DSM $16850^{\mathrm{T}} ; 12$, M. suwonensis KACC $12635^{\mathrm{T}}$. Data for reference strains were taken from Zul et al. (2008) (M. brevitalea DSM $18925^{\mathrm{T}}$ ), Weon et al. (2009) (M. niabensis DSM $21312^{\mathrm{T}}$ and M. niastensis DSM 21313 ${ }^{\mathrm{T}}$ ), Weon et al. (2010) (M. suwonensis KACC 12635 ${ }^{\mathrm{T}}$ ) and Weon et al. $(2008$ ) (remaining strains) unless otherwise indicated. The reported data were obtained on the basis of the same and/or comparable conditions. In API 20NE tests, all strains are negative for indole production, glucose fermentation, arginine dihydrolase and assimilation of D-mannitol. In API ZYM tests, all strains are positive for alkaline phosphatase, leucine arylamidase, valine arylamidase, naphthol-AS-BI-phosphohydrolase, acid phosphatase and esterase (C4), but negative for lipase (C14), $N$-acetyl- $\beta$-glucosaminidase, $\alpha$-mannosidase and $\alpha$-fucosidase. W, Weakly positive; ND, no data available.

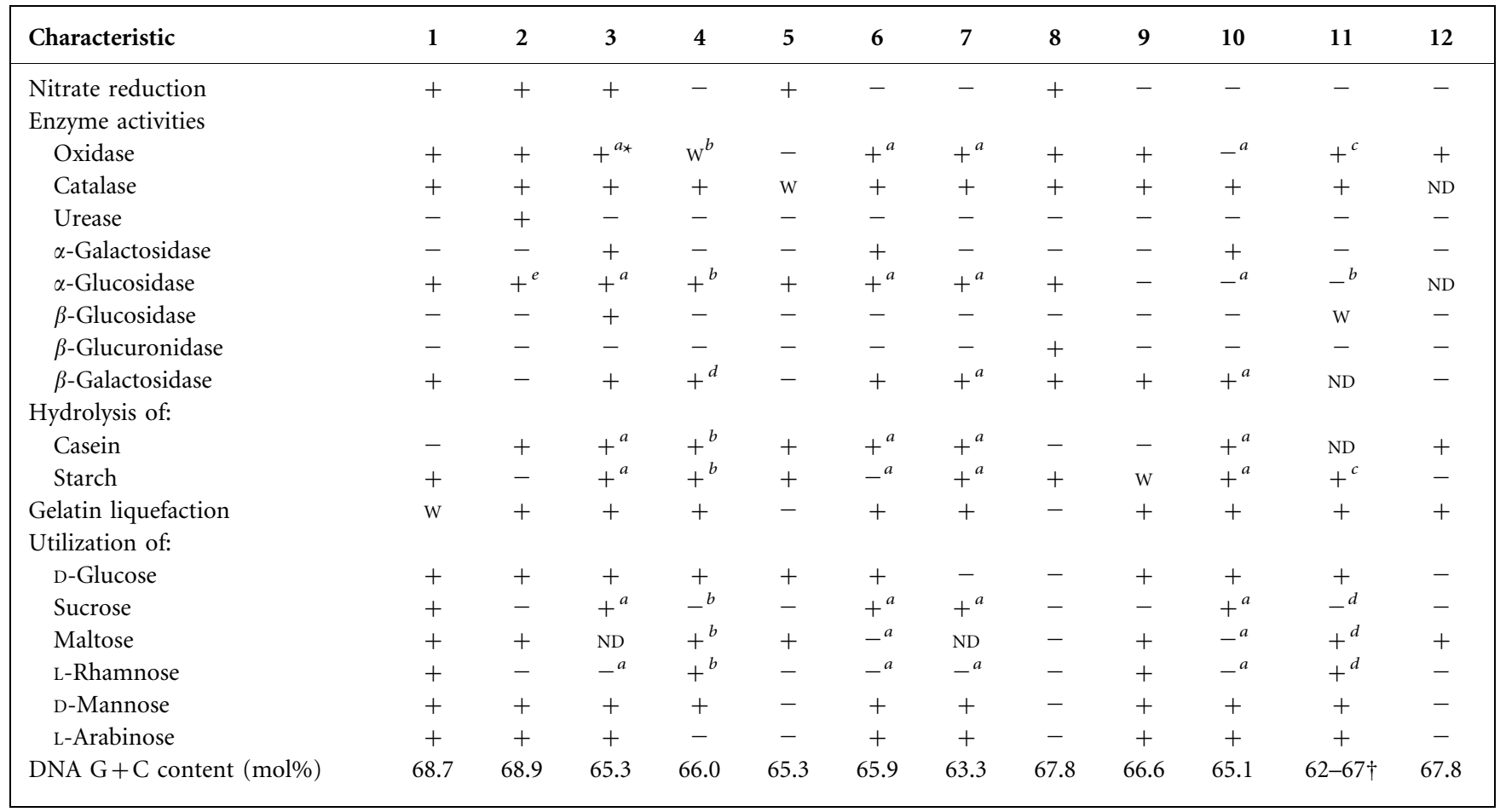

${ }^{\star}$ Data taken from: $a$, Zhang et al. (2006); b, Gallego et al. (2006); c, Lindquist et al. (2003); d, Zul et al. (2008).

$\nmid$ Range of values for a number of strains including the type strain (Lindquist et al., 2003). 
Table 2. Cellular fatty acid compositions of strain $\mathrm{Y}^{\top}$ and the type strains of closely related species of the genus Massilia

Strains: 1 , Y9 ${ }^{\mathrm{T}}$; 2, M. albidiflava KCTC $12343^{\mathrm{T}} ; 3$, M. dura KCTC $12342^{\mathrm{T}} ; 4$, M. lutea KCTC $12345^{\mathrm{T}}$; 5, M. niabensis DSM $21312^{\mathrm{T}}$; 6, M. niastensis DSM $21313^{\mathrm{T}} ; 7$, M. timonae DSM $16850^{\mathrm{T}} ; 8$, M. suwonensis KACC $12635^{\mathrm{T}}$. Data in columns $2-4$ were taken from Zhang et al. (2006) and data in columns 5-8 were taken from Weon et al. (2010). The reported data were obtained under the same or comparable conditions. Values are percentages of the total fatty acids; -, not present/not reported.

\begin{tabular}{|c|c|c|c|c|c|c|c|c|}
\hline Fatty acid & 1 & 2 & 3 & 4 & 5 & 6 & 7 & 8 \\
\hline $\mathrm{C}_{10: 0} 3-\mathrm{OH}$ & 2.7 & 9.6 & 8.3 & 4.6 & 6.6 & 5.5 & 4.6 & 5.4 \\
\hline $\mathrm{C}_{12: 0}$ & 3.0 & 6.0 & 5.6 & 2.8 & 8.9 & 4.7 & 3.3 & 4.4 \\
\hline $\mathrm{C}_{12: 0} 2-\mathrm{OH}$ & - & 0.7 & - & - & - & 2.4 & 2.2 & 2.4 \\
\hline $\mathrm{C}_{14: 0}$ & 6.9 & 2.8 & 3.2 & 1.9 & - & - & - & 1.2 \\
\hline $\mathrm{C}_{14: 0} 2-\mathrm{OH}$ & 1.5 & 3.0 & 3.4 & 2.0 & - & - & - & - \\
\hline $\mathrm{C}_{16: 0}$ & 26.1 & 22.8 & 25.5 & 22.8 & 23.6 & 26.9 & 30.5 & 28.8 \\
\hline iso- $\mathrm{C}_{16: 0}$ & 1.6 & - & - & - & - & - & - & - \\
\hline $\mathrm{C}_{17: 0}$ cyclo & - & - & - & - & - & 3.4 & 3.7 & 2.9 \\
\hline iso- $\mathrm{C}_{17: 1} \omega 9 c$ & - & - & - & 0.7 & - & - & - & - \\
\hline $\mathrm{C}_{18: 1} \omega 7 c$ & 9.9 & 7.4 & 5.9 & 10.0 & 7.8 & 12.3 & 7.9 & 7.8 \\
\hline $\mathrm{C}_{18: 0}$ & 3.2 & - & - & - & - & - & - & - \\
\hline $\mathrm{C}_{20: 0}$ & - & - & - & - & - & 2.6 & - & - \\
\hline Summed feature $3^{\star}$ & 35.8 & 46.4 & 46.7 & 54.7 & 46.0 & 38.1 & 47.0 & 45.8 \\
\hline
\end{tabular}

*Summed features are groups of two or three fatty acids that cannot be separated by GLC with the MIDI Sherlock version 4.5 system. Summed feature 3 contained $\mathrm{C}_{16: 1} \omega 7 c$ and/or iso- $\mathrm{C}_{15: 0} 2-\mathrm{OH}$. The database used was TSBA40.

1996). The predominant isoprenoid quinone in strain $Y 9^{\mathrm{T}}$ was Q-8. The polar lipid profile of strain $\mathrm{Y}^{\mathrm{T}}$ contained major amounts of phosphatidylethanolamine, phosphatidylglycerol and diphosphatidylglycerol and moderate amounts of an unknown phospholipid and an unknown aminolipid (Supplementary Fig. S1, available in IJSEM Online). The DNA $\mathrm{G}+\mathrm{C}$ content of strain $\mathrm{Y}^{\mathrm{T}}$ was $68.7 \mathrm{~mol} \%$. The fatty acid profile of strain $\mathrm{Y}^{\mathrm{T}}$ contained summed feature $3\left(\mathrm{C}_{16: 1} \omega 7 \mathrm{c}\right.$ and/or iso- $\mathrm{C}_{15: 0} 2-\mathrm{OH}$; $35.8 \%)$ and $\mathrm{C}_{16: 0}(26.1 \%)$ as major components and moderate amounts of $\mathrm{C}_{18: 1} \omega 7 c(9.9 \%), \mathrm{C}_{12: 0}(3.0 \%)$ and $\mathrm{C}_{10: 0} 3-\mathrm{OH}(2.7 \%)$, which were also found for recognized species of the genus Massilia. However, in comparison with recognized Massilia species, the fatty acid profile of strain $\mathrm{Y} 9^{\mathrm{T}}$ showed relatively large amounts of $\mathrm{C}_{14: 0}(6.9 \%)$ and $\mathrm{C}_{18: 0}(3.2 \%)$. Comparisons of the fatty acid profiles of the novel isolate and recognized members of the genus Massilia are given in Table 2. The major respiratory quinone, DNA $\mathrm{G}+\mathrm{C}$ content and fatty acid profile of strain $\mathrm{Y}^{\mathrm{T}}$ were all consistent with the properties of the genus Massilia.

Extraction of genomic DNA and amplification of the $16 \mathrm{~S}$ rRNA gene were performed as described by Rainey et al. (1996). The PCR product was sequenced directly by using the method of Lu et al. (2001). Sequence gel electrophoresis was performed and nucleotide sequences were obtained automatically by using an Applied Biosystems DNA sequencer (model 377) and software provided by the manufacturer. The resultant 16S rRNA gene sequence was compared with those available in GenBank, by using the BLAST program. Multiple alignment with sequences from closely related species was performed with the CLUSTAL X 1.8 program (Thompson et al., 1997). Levels of $16 \mathrm{~S}$ rRNA gene sequence similarity were calculated by using the EzTaxon server (http://www.eztaxon. org; Chun et al., 2007). Phylogenetic dendrograms were constructed by using the neighbour-joining (Saitou \& Nei, 1987) and maximum-parsimony (Kluge \& Farris, 1969) methods in MEGA, version 4.1 (Tamura et al., 2007), with bootstrap values based on 1000 replications. Evolutionary distance matrices were generated following Kimura (1980). The almost-complete 16S rRNA gene sequence was obtained for strain $\mathrm{Y}^{\mathrm{T}}(1406 \mathrm{nt})$. Comparative 16S rRNA gene sequence analyses showed that strain $\mathrm{Y}^{\mathrm{T}}$ was affiliated phylogenetically with species of the genus Massilia. Strain $\mathrm{Y} 9^{\mathrm{T}}$ showed levels of $16 \mathrm{~S}$ rRNA gene sequence similarity of 95.2-98.2\% with respect to the type strains of recognized Massilia species, the highest levels being with Massilia albidiflava $45^{\mathrm{T}}(98.2 \%)$, Massilia lutea $101^{\mathrm{T}}(98.0 \%)$, Massilia niastensis 5516S- $1^{\mathrm{T}}$ (97.3\%), Massilia niabensis $5420 \mathrm{~S}-26^{\mathrm{T}}(97.0 \%)$ and Duganella violaceinigra YIM $31327^{\mathrm{T}}$ $(97.0 \%)$. Other strains showed less than $97 \%$ 16S rRNA gene sequence similarity. Strain $\mathrm{Y}^{\mathrm{T}}$ showed relatively low sequence similarities $(<95.6 \%)$ with respect to members of other genera of the family Oxalobacteraceae, expect for $D$. violaceinigra. A phylogenetic tree based on the neighbourjoining method is shown in Fig. 1. Strain $\mathrm{Y}^{\mathrm{T}}$ fell within the evolutionary radius of the genus Massilia, clustering with $M$. timonae, the type species of the genus Massilia. The maximum-parsimony tree also supported the clustering of strain $\mathrm{Y}^{\mathrm{T}}$ and recognized Massilia species.

The major cellular fatty acids of strain $\mathrm{Y}^{\mathrm{T}}$ were summed feature 3 and $\mathrm{C}_{16: 0}$, identical to data for $M$. timonae DSM $16850^{\mathrm{T}}$. They also shared some common phenotypic characteristics (Table 1). Phylogenetically, strain $\mathrm{Y9}^{\mathrm{T}}$ grouped with Massilia species and clustered with M. timonae 


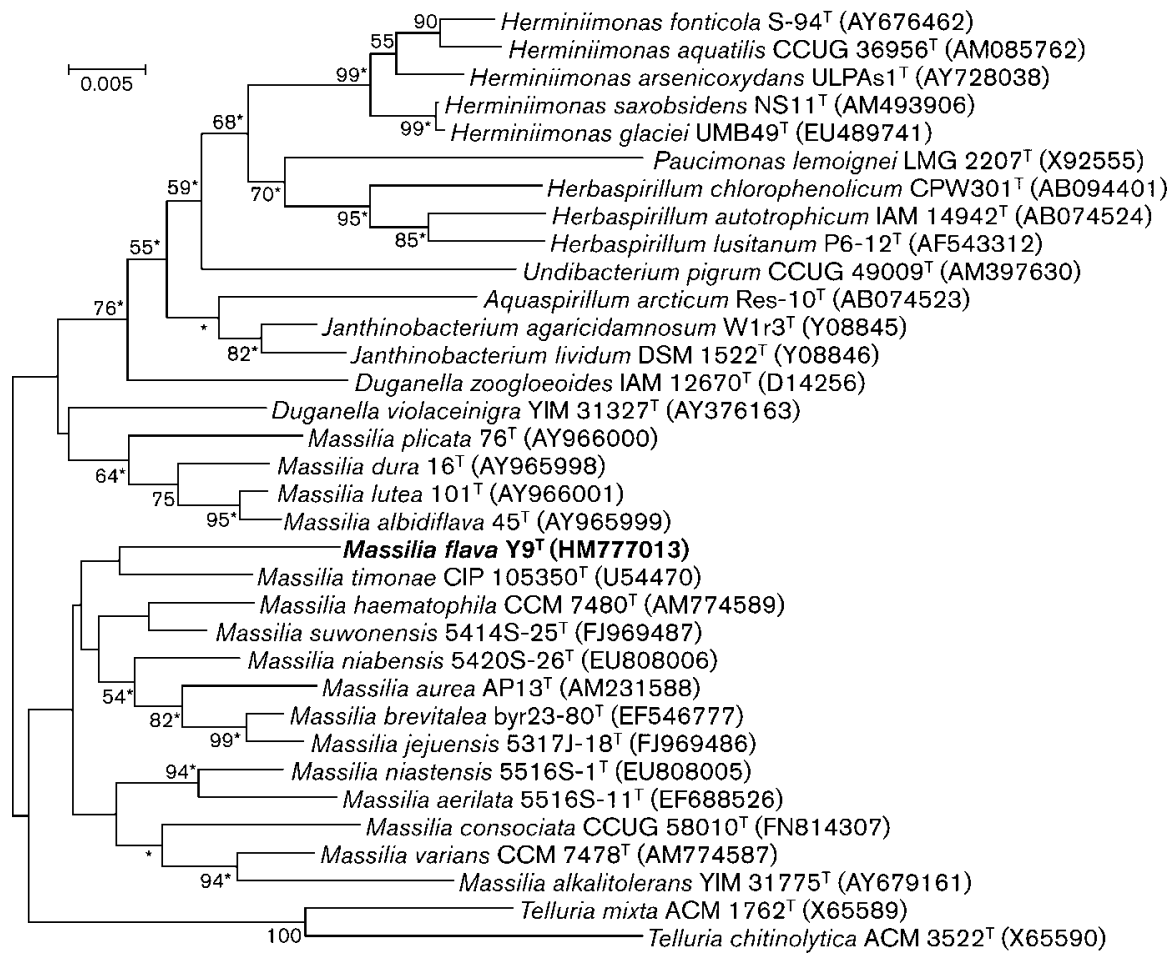

Fig. 1. Neighbour-joining phylogenetic tree based on $16 \mathrm{~S}$ rRNA gene sequences, showing the relationships between strain $\mathrm{Y}^{\top}$ and closely related species. Asterisks indicate that the corresponding branches were also recovered in the maximumparsimony tree. Bootstrap values based on 1000 replications are listed as percentages; only values $>50 \%$ are given. Bar, 0.005 substitutions per nucleotide position.

DSM $16850^{\mathrm{T}}$. Therefore, strain $\mathrm{Y} 9^{\mathrm{T}}$ should be assigned to the genus Massilia.

DNA-DNA hybridization experiments among strain $\mathrm{Y}^{\mathrm{T}}$ and its closest phylogenetic neighbours, $M$. albidiflava KCTC $12343^{\mathrm{T}}$, M. lutea KCTC $12345^{\mathrm{T}}$, M. niastensis DSM $21313^{\mathrm{T}}, M$. niabensis DSM $21312^{\mathrm{T}}$ and D. violaceinigra KCTC $12193^{\mathrm{T}}$, were carried out applying the optical renaturation method (De Ley et al., 1970; Huß et al., 1983; Jahnke, 1992) under optimal hybridization conditions. Mean DNA-DNA relatedness between strain $\mathrm{Y}^{\mathrm{T}}$ and $M$. albidiflava KCTC $12343^{\mathrm{T}}$, M. lutea KCTC $12345^{\mathrm{T}}, M$. niastensis DSM $21313^{\mathrm{T}}, M$. niabensis DSM $21312^{\mathrm{T}}$ and $D$. violaceinigra $\mathrm{KCTC} 12193^{\mathrm{T}}$ was $37,26,21,20$ and $20 \%$, respectively. These values were significantly lower than the threshold value of $70 \%$ that is commonly accepted for the definition of bacterial species (Wayne et al., 1987).

Strain $\mathrm{Y}^{\mathrm{T}}$ showed a range of phenotypic characteristics that differentiated it from recognized species of the genus Massilia (Table 1). In addition, the results of our phylogenetic analysis (Fig. 1) and DNA-DNA relatedness experiments differentiate strain $\mathrm{Y}^{\mathrm{T}}$ from recognized Massilia species. It is apparent that strain $\mathrm{Y}^{\mathrm{T}}$ is not affiliated to any recognized species of the genus Massilia. Therefore, on the basis of the data presented above, strain $\mathrm{Y} 9^{\mathrm{T}}$ represents a novel species of the genus Massilia, for which the name Massilia flava sp. nov. is proposed.

\section{Description of Massilia flava sp. nov.}

Massilia flava (fla'va. L. fem. adj. flava yellow, pertaining to the yellow colony colour).

Cells are Gram-stain-negative, aerobic rods, $0.6-0.8 \mu \mathrm{m}$ wide and 1.5-2.5 $\mu \mathrm{m}$ long. Colonies are circular to irregular, convex, yellow and $1-3 \mathrm{~mm}$ in diameter after 3 days cultivation at $28{ }^{\circ} \mathrm{C}$ on ISP2 medium. Growth occurs at $10-45{ }^{\circ} \mathrm{C}$ (optimal growth at $28-30{ }^{\circ} \mathrm{C}$ ) and $\mathrm{pH} 6.5-8.5$ (optimal growth at $\mathrm{pH} 7.0-7.5$ ). Growth occurs with $0-1 \%$ $\mathrm{NaCl}$ (optimal growth without $\mathrm{NaCl}$ ). Positive for catalase, oxidase and $\beta$-galactosidase (ONPG test), weakly positive for tryptophan deaminase and negative for urease, arginine dihydrolase, lysine decarboxylase and ornithine decarboxylase. Degrades starch and Tweens 20 and 80, but not casein or tyrosine. Nitrate is reduced. Neither indole nor hydrogen sulfide is produced. Methyl red reaction is negative. Milk coagulation and peptonization are positive. In API ZYM tests, positive for alkaline phosphatase, acid phosphatase, esterase (C4), leucine arylamidase, valine arylamidase, cystine arylamidase, trypsin, chymotrypsin, naphthol-ASBI-phosphohydrolase, $\beta$-galactosidase and $\alpha$-glucosidase, but negative for esterase lipase (C8), lipase (C14), $\alpha$ galactosidase, $\beta$-glucuronidase, $\beta$-glucosidase, $N$-acetylglucosaminidase, $\alpha$-mannosidase and $\alpha$-fucosidase. Assimilates L-arabinose, cellobiose, D-fucose, D-galactose, D-glucose, glycogen, lactose, maltose, L-rhamnose, sucrose, trehalose 
and D-xylose. Weakly assimilates arbutin, D-fructose and Dmannose. Does not assimilate D-arabinose, D- or L-arabitol, L-fucose, $N$-acetyl-D-glucosamine, glycerol, myo-inositol, mannitol, melezitose, melibiose, raffinose, D-ribose, Dsorbitol, L-sorbose, D-tagatose, D-xylitol or L-xylose. The predominant ubiquinone is Q-8. The major polar lipids are phosphatidylethanolamine, phosphatidylglycerol and diphosphatidylglycerol. The major fatty acids are summed feature 3 $\left(\mathrm{C}_{16: 1} \omega 7 c\right.$ and/or iso- $\left.\mathrm{C}_{15: 0} 2-\mathrm{OH}\right), \mathrm{C}_{16: 0}$ and $\mathrm{C}_{18: 1} \omega 7 c$. The $\mathrm{G}+\mathrm{C}$ content of the DNA of the type strain is $68.7 \mathrm{~mol} \%$.

The type strain, $\mathrm{Y}^{\mathrm{T}} \quad\left(=\mathrm{CGMCC} 1.10685^{\mathrm{T}}=\mathrm{KCTC}\right.$ $23585^{\mathrm{T}}$ ), was isolated from a soil sample collected from Ningxia Province, China. The species description is based on a single strain and hence serves as a description of the type strain.

\section{Acknowledgements}

This research was supported by the National Natural Science Foundation of China (NSFC) (grant nos 31070002 and 30970009), the Special Fund for Public Welfare Industrial (Agriculture) Research of China (grant no. 200903001) and the Basic Research Foundation of Beijing Institute of Technology (grant no. 20091642006). We are grateful to Dr Yafang Tan for quantitative fatty acid analysis of strain $\mathrm{Y} 9^{\mathrm{T}}$.

\section{References}

Chun, J., Lee, J. H., Jung, Y., Kim, M., Kim, S., Kim, B. K. \& Lim, Y. W. (2007). EzTaxon: a web-based tool for the identification of prokaryotes based on $16 \mathrm{~S}$ ribosomal RNA gene sequences. Int J Syst Evol Microbiol 57, 2259-2261.

Collins, M. D. \& Jones, D. (1980). Lipids in the classification and identification of coryneform bacteria containing peptidoglycans based on 2,4-diaminobutyric acid. J Appl Bacteriol 48, 459-470.

Collins, M. D., Howarth, O. W., Grund, E. \& Kroppenstedt, R. M. (1987). Isolation and structural determination of new members of the vitamin $\mathrm{K}_{2}$ series in Nocardia brasiliensis. FEMS Microbiol Lett 41, 35-39.

De Ley, J., Cattoir, H. \& Reynaerts, A. (1970). The quantitative measurement of DNA hybridization from renaturation rates. Eur $J$ Biochem 12, 133-142.

Gallego, V., Sánchez-Porro, C., Garcia, M. T. \& Ventosa, A. (2006). Massilia aurea sp. nov., isolated from drinking water. Int J Syst Evol Microbiol 56, 2449-2453.

Huß, V. A. R., Festl, H. \& Schleifer, K. H. (1983). Studies on the spectrophotometric determination of DNA hybridization from renaturation rates. Syst Appl Microbiol 4, 184-192.

Jahnke, K.-D. (1992). Basic computer program for evaluation of spectroscopic DNA renaturation data from Gilford System 2600 spectrophotometer on a $\mathrm{PC} / \mathrm{XT} / \mathrm{AT}$ type personal computer. J Microbiol Methods 15, 61-73.

Kämpfer, P. \& Kroppenstedt, R. M. (1996). Numerical analysis of fatty acid patterns of coryneform bacteria and related taxa. Can $J$ Microbiol 42, 989-1005.

Kämpfer, P., Falsen, E. \& Busse, H.-J. (2008). Naxibacter varians sp. nov. and Naxibacter haematophilus sp. nov., and emended description of the genus Naxibacter. Int J Syst Evol Microbiol 58, 1680-1684.

Kämpfer, P., Lodders, N., Martin, K. \& Falsen, E. (2011). Revision of the genus Massilia La Scola et al. 2000, with an emended description of the genus and inclusion of all species of the genus Naxibacter as new combinations, and proposal of Massilia consociata sp. nov. Int J Syst Evol Microbiol 61, 1528-1533.

Kimura, M. (1980). A simple method for estimating evolutionary rates of base substitutions through comparative studies of nucleotide sequences. J Mol Evol 16, 111-120.

Kluge, A. G. \& Farris, F. S. (1969). Quantitative phyletics and the evolution of anurans. Syst Zool 18, 1-32.

La Scola, B., Birtles, R. J., Mallet, M. N. \& Raoult, D. (1998). Massilia timonae gen. nov., sp. nov., isolated from blood of an immunocompromised patient with cerebellar lesions. J Clin Microbiol 36, 28472852.

Lindquist, D., Murrill, D., Burran, W. P., Winans, G., Janda, J. M. \& Probert, W. (2003). Characteristics of Massilia timonae and Massilia timonae-like isolates from human patients, with an emended description of the species. J Clin Microbiol 41, 192-196.

Lu, Z., Liu, Z., Wang, L., Zhang, Y., Qi, W. \& Goodfellow, M. (2001). Saccharopolyspora flava sp. nov. and Saccharopolyspora thermophila sp. nov., novel actinomycetes from soil. Int J Syst Evol Microbiol 51, 319-325.

Marmur, J. \& Doty, P. (1962). Determination of the base composition of deoxyribonucleic acid from its thermal denaturation temperature. J Mol Biol 5, 109-118.

Minnikin, D. E., Collins, M. D. \& Goodfellow, M. (1979). Fatty acid and polar lipid composition in the classification of Cellulomonas, Oerskovia and related taxa. J Appl Bacteriol 47, 87-95.

Rainey, F. A., Ward-Rainey, N., Kroppenstedt, R. M. \& Stackebrandt, E. (1996). The genus Nocardiopsis represents a phylogenetically coherent taxon and a distinct actinomycete lineage: proposal of Nocardiopsaceae fam. nov. Int J Syst Bacteriol 46, 1088-1092.

Saitou, N. \& Nei, M. (1987). The neighbor-joining method: a new method for reconstructing phylogenetic trees. Mol Biol Evol 4, 406-425.

Sasser, M. (1990). Identification of bacteria by gas chromatography of cellular fatty acids, Technical Note 101. Newark, DE: MIDI, Inc.

Smibert, R. M. \& Krieg, N. R. (1994). Phenotypic characterization. In Methods for General and Molecular Bacteriology, pp. 607-654. Edited by P. Gerhardt, R. G. E. Murray, W. A. Wood \& N. R. Krieg. Washington, DC: American Society for Microbiology.

Tamura, K., Dudley, J., Nei, M. \& Kumar, S. (2007). MEGA4: molecular evolutionary genetics analysis (MEGA) software version 4.0. Mol Biol Evol 24, 1596-1599.

Thompson, J. D., Gibson, T. J., Plewniak, F., Jeanmougin, F. \& Higgins, D. G. (1997). The CLUSTAL_X windows interface: flexible strategies for multiple sequence alignment aided by quality analysis tools. Nucleic Acids Res 25, 4876-4882.

Wayne, L. G., Brenner, D. J., Colwell, R. R., Grimont, P. A. D., Kandler, O., Krichevsky, M. I., Moore, L. H., Moore, W. E. C., Murray, R. G. E. \& other authors (1987). International Committee on Systematic Bacteriology. Report of the ad hoc committee on reconciliation of approaches to bacterial systematics. Int J Syst Bacteriol 37, 463-464.

Weon, H. Y., Kim, B. Y., Son, J. A., Jang, H. B., Hong, S. K., Go, S. J. \& Kwon, S. W. (2008). Massilia aerilata sp. nov., isolated from an air sample. Int J Syst Evol Microbiol 58, 1422-1425.

Weon, H. Y., Kim, B. Y., Hong, S. B., Jeon, Y. A., Koo, B. S., Kwon, S. W. \& Stackebrandt, E. (2009). Massilia niabensis sp. nov. and Massilia niastensis sp. nov., isolated from air samples. Int J Syst Evol Microbiol 59, 1656-1660.

Weon, H. Y., Yoo, S. H., Kim, S. J., Kim, Y. S., Anandham, R. \& Kwon, S. W. (2010). Massilia jejuensis sp. nov. and Naxibacter suwonensis sp. nov., isolated from air samples. Int J Syst Evol Microbiol 60, 19381943. 
Wu, C., Lu, X., Qin, M., Wang, Y. \& Ruan, J. (1989). Analysis of menaquinone compound in microbial cells by HPLC. Microbiology [English translation of Microbiology (Beijing)] 16, 176-178.

Xu, P., Li, W.-J., Tang, S.-K., Zhang, Y.-Q., Chen, G.-Z., Chen, H.-H., Xu, L.-H. \& Jiang, C.-L. (2005). Naxibacter alkalitolerans gen. nov., sp. nov., a novel member of the family 'Oxalobacteraceae' isolated from China. Int J Syst Evol Microbiol 55, 1149-1153.
Zhang, Y.-O., Li, W.-J., Zhang, K.-Y., Tian, X.-P., Jiang, Y., Xu, L.-H., Jiang, C.-L. \& Lai, R. (2006). Massilia dura sp. nov., Massilia albidiflava sp. nov., Massilia plicata sp. nov. and Massilia lutea sp. nov., isolated from soils in China. Int J Syst Evol Microbiol 56, 459-463.

Zul, D., Wanner, G. \& Overmann, J. (2008). Massilia brevitalea sp. nov., a novel betaproteobacterium isolated from lysimeter soil. Int $J$ Syst Evol Microbiol 58, 1245-1251. 